УДК 616.314.25-007.481-092:08

DOI 10.11603/2311-9624.2018.1.8359

(C). В. Мандич

Львівський національний медичний університет імені Данила Галицького

\title{
Індексна оцінка стану тканин пародонта в осіб молодого віку 3 хронічним катаральним гінгівітом на тлі скупчення зубів
}

Резюме. На сьогодні відомо, що серед аномалій зубощелепної системи тісне положення зубів займає провідне місце i, найчастіше супроводжуючись захворюваннями пародонта, ураженням твердих тканин зубів, функціональними порушеннями зубощелепної системи та психоемоційними розладами пацієнтів, становить актуальну проблему в стоматології. Дослідники констатували факт підвищення активності перебігу захворювань пародонта у пацієнтів із зубощелепними аномаліями.

Мета дослідження - оцінити інтенсифікацію запальних процесів тканин пародонта в осіб молодого віку зі скупченням зубів за допомогою пародонтологічних індексів.

Матеріали і методи. У статті показано порівняльну оцінку інтенсивності запальних процесів у тканинах пародонта в 104 осіб віком 18-35 років, із хронічним катаральним гінгівітом (ХКГ) на тлі скупчення зубів (основна група) та 33 людей із ХКГ без ортодонтичної патології (порівняльна група). Для оцінки стану тканин пародонта використовували індекси РМА, кровоточивості ясен та СРI. Отримані результати опрацьовано статистично.

Результати досліджень та їх обговорення. За результатами досліджень встановлено, що залежно від ступеня тяжкості ХКГ та зі збільшенням віку обстежених зростає інтенсивність запальних процесів у тканинах зубоутримувального апарату в обох групах дослідження, однак в осіб із ХКГ на тлі скупчення зубів ця тенденція носила більш виражений характер. Встановлено, що середнє значення індексу РМА, за критеріями індексу, відповідало гінгівіту середнього ступеня тяжкості в основній та порівняльній групах дослідження. Зі збільшенням віку обстежених обох груп дослідження, визначали зростання даних індексу кровоточивості. У пацієнтів зі скупченням зубів значення індексу СРI перевищували значення даного індексу в осіб без ортодонтичної патології.

Висновки. В осіб зі скупченням зубів на тлі хронічного катарального гінгівіту інтенсифікація запальних процесів у тканинах пародонта збільшувалась з віком, залежала від ступеня тяжкості ХКГ та була вищою, ніж у обстежених без ортодонтичної патології.

Ключові слова: захворювання тканин пародонта; зубощелепні аномалії; скупчення зубів.

\section{(C)А. В. Мандыч}

Львовский национальный медицинский университет имени Данила Галицкого

\section{Индексная оценка состояния тканей пародонта у лиц молодого возраста с хроническим катаральным гингивитом на фоне скученности зубов}

Резюме. На сегодня известно, что среди аномалий зубочелюстной системы тесное положение зубов занимает ведущее место и, зачастую сопровождаясь заболеваниями пародонта, поражением твердых тканей зубов, функциональными нарушениями зубочелюстной системы и психоэмоциональными расстройствами пациентов, составляет актуальную проблему в стоматологии. Исследователями констатирован факт повышения активности течения заболеваний пародонта у пациентов с зубочелюстными аномалиями.

Цель исследования - оценить интенсификацию воспалительных процессов тканей пародонта в лиц молодого возраста со скупченностью зубов с помощью пародонтологических индексов.

Материалы и методы. В статье приведена сравнительная оценка интенсивности воспалительных процессов в тканях пародонта у 104 человек в возрасте 18-35 лет, с хроническим катаральным гингивитом (ХКГ) на фоне скученности зубов (основная группа) и 33 людей с ХКГ без ортодонтической патологии (сравнительная группа). Для оценки состояния тканей пародонта использовались индексы PMA, кровоточивости десен и СРІ. Полученные результаты обработаны статистически.

Результаты исследований и их обсуждение. По результатам исследований установлено, что в зависимости от степени тяжести ХКГ и с увеличением возраста обследованных возрастает интенсивность воспалительных процессов в тканях зубоудерживающего аппарата в обеих группах исследования, однако у лиц с ХКГ на фоне скученности зубов эта тенденция носила более выраженный характер. 
Установлено, что среднее значение индекса РМА, по критериям индекса, соответствовало гингивиту средней степени тяжести в основной и сравнительной группах исследования. С увеличением возраста обследованных обеих групп исследования, определяли рост данных индекса кровоточивости. У пациентов со скученностью зубов значения индекса CPI превышали значения данного индекса у лиц без ортодонтической патологии.

Выводы. У лиц со скученностью зубов на фоне хронического катарального гингивита интенсификация воспалительных процессов в тканях пародонта увеличивалась с возрастом, зависела от степени тяжести ХКГ и была выше, чем у обследованных без ортодонтической патологии.

Ключевые слова: заболевания тканей пародонта; зубочелюстные аномалии; скученность зубов.

\section{(C) O. V. Mandych}

Danylo Halytskyi Lviv National Medical University

\section{Index estimation of the state of periodontal tissues in young individuals with chronic catarrhal gingivitis on the background of crowding of teeth}

Summary. Today it is known that among maxillodental abnormalities crowded teeth have a leading position and often accompanied by periodontal diseases, lesions of the hard dental tissues, functional disorders of maxillodental system and psycho-emotional disorders of patients is a relevant problem in dentistry. The researchers ascertained the fact of increasing the activity of the course of periodontal disease in patients with maxillodental abnormalities.

The aim of the study - to estimate the intensification of inflammatory processes in periodontal tissues of young individuals with crowding of the teeth using periodontal indices.

Materials and Methods. The article presents the comparative estimation of the intensity of inflammatory processes in periodontal tissues from 104 people in the age of 18-35 years with chronic catarrhal gingivitis (CCG) on the background of crowding of teeth (main group) and 33 people with CCG without orthodontic pathology (comparison group). For the estimation of the state of periodontal tissues the indexes PMA, bleeding gums and CPI were used. The obtained data were worked out statistically.

Results and Discussion. It is set on the results of studies that in dependence on the degree of severity of CCG and with increase of the age of examined increases the intensity of inflammatory processes in tissues of teethrestraint apparatus in both study groups, but in patients with CCG on the background of crowding of teeth this tendency was more pronounced. The average value of the PMA index by its criteria of index revealed to gingivitis of the average severity in the main and comparison groups of the study. With the increase of age of patients in both study groups the increase of the index of bleeding was set. In patients with crowding teeth the values of CPI index exceeded the values of the index in individuals without orthodontic pathology.

Conclusions. In patients with crowded teeth on the background of chronic catarrhal gingivitis the intensification of inflammatory processes in periodontal tissues increased with age and depended on the severity of chronic catarrhal gingivitis and was higher than in patients without orthodontic pathology.

Key words: diseases of periodontal tissues; maxillodental abnormalities; crowding of teeth.

Вступ. Відомо, що аномалії зубощелепної системи є однією з найпоширеніших патологій у людей і провідне місце серед них має скупчене положення зубів $[1,3,6]$. Встановлено, що тісне положення зубів у більшості випадків супроводжується захворюваннями пародонта, ураженням твердих тканин зубів, функціональними порушеннями зубощелепної системи та психоемоційними розладами пацієнтів [7, 9].

Дослідники констатували факт підвищення активності перебігу захворювань пародонта в пацієнтів із зубощелепними аномаліями. Інтенсифікацію уражень тканин зубоутримувального апарату частіше всього пов'язують зі складністю видалення зубної бляшки стандартними засобами гігієни порожнини рота [3, 4]. Встановлено, що при наявності зубощелених аномалій розвивається дисфункція жувального апарату, при якому порушується координована робота жувальних м'язів, змінюється симетричність рухів нижньої щелепи 3 можливим розвитком патологічних змін у скронево-нижньощелепному суглобі $[1,6]$.

У результаті зниження жувальних та функціональних навантажень погіршується метаболізм у тканинах пародонта, що призводить до рецесії ясен і атрофії альвеолярної кістки $[2,3,6]$. Отже, наявність зубощелепних анома- 
лій, зокрема скупчення зубів, призводить до розвитку регіонарної вазоконстрикції і тканинної гіпоксії, зменшення рівня інтенсивності обмінних процесів, до деструкції тканин пародонта.

При цьому ортодонтичне лікування тісного положення зубів із використанням ортодонтичної апаратури може мати негативний вплив на тканини пародонта, погіршувати стан гігієни ротової порожнини пацієнтів [1, 3].

Метою дослідження було оцінити інтенсифікацію запальних процесів у тканинах пародонта осіб молодого віку зі скупченням зубів за допомогою пародонтологічних індексів.

Матеріали і методи. У 104 осіб зі скупченням зубів на тлі хронічного катарального гінгівіту (ХКГ) (основна група) та 33 пацієнтів із
ХКГ без ортодонтичної патології (порівняльна група) проведено оцінку стану тканин пародонта за допомогою індексів РМА, індексу кровоточивості ясен та індексу CPI, залежно від віку досліджуваних і ступеня тяжкості ХКГ [3]. Отримані результати опрацьовано статистично за допомогою функцій MS Excel i Statistica 6.

Результати досліджень та їх обговорення. У результаті проведених досліджень ми встановили (рис. 1), що у середньому в 18-26-річних пацієнтів значення індексу РМА становило $(42,18 \pm 2,48) \%$, що за критеріями індексу засвідчувало гінгівіт середнього ступеня тяжкості, та було у 1,9 раза вище стосовно даних у групі порівняння - $(21,73 \pm 2,11) \%, \mathrm{p}<0,01$, що, у свою чергу, характеризувало як гінгівіт легкого ступеня тяжкості.

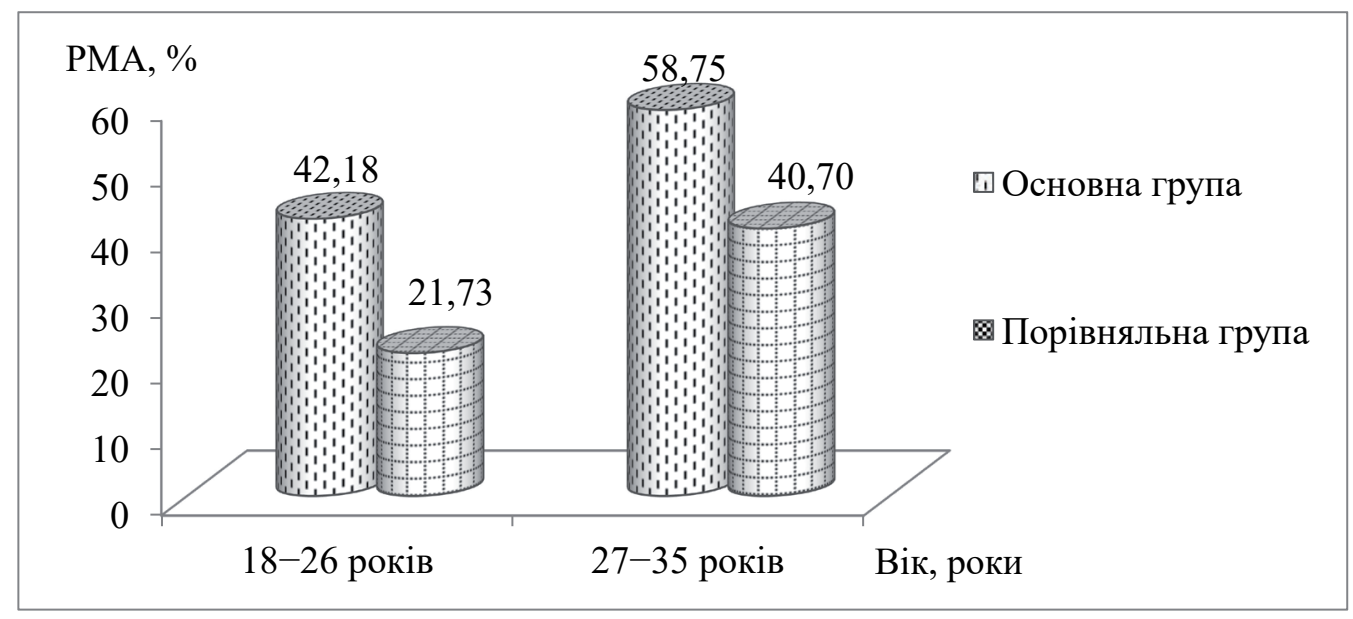

Puc. 1. Середні значення індексу РМА залежно від віку оглянутих пацієнтів.

У пацієнтів зі скупченням зубів у віковій групі 27-35 років середнє значення індексу PMA дорівнювало $(58,75 \pm 2,31) \%$ та було в 1,4 раза вище, ніж у їх однолітків без ортодонтичної патології - $(40,70 \pm 2,14) \% \mathrm{p}<0,01$, та за критеріями індексу вказувало на гінгівіт середнього ступеня в обох групах дослідження.

Отже, у середньому в пацієнтів зі скупченням зубів середнє значення індексу РМА скла- дало $(50,47 \pm 2,40) \%$ проти $(31,22 \pm 2,13) \%, p<0,01$ у порівняльній групі та, за критеріями індексу, відповідало гінгівіту середнього ступеня тяжкості в обох групах дослідження.

Структуру тяжкості хронічного катарального гінгівіту в осіб груп дослідження за критеріями індексу РМА наведено у таблиці 1. Аналіз даних, представлених у таблиці, показав, що у 18-26-річних осіб основної групи при легко-

таблиия 1. Структура тяжкості хронічного катарального гінгівіту в пацієнтів груп дослідження за критерієм PMA (\%)

\begin{tabular}{|c|c|c|c|c|c|c|}
\hline \multirow{2}{*}{$\begin{array}{c}\text { Вікова } \\
\text { група, } \\
\text { роки }\end{array}$} & \multicolumn{3}{|c|}{ Основна група (n=104) } & \multicolumn{3}{c|}{ Порівняльна група (n=33) } \\
\cline { 2 - 7 } & $\begin{array}{c}\text { легкий } \\
\text { стпінь, РМА }\end{array}$ & $\begin{array}{c}\text { середній } \\
\text { ступінь, РМА }\end{array}$ & $\begin{array}{c}\text { тяжкий } \\
\text { ступінь, РМА }\end{array}$ & $\begin{array}{c}\text { легкий } \\
\text { ступінь, РМА }\end{array}$ & $\begin{array}{c}\text { середній } \\
\text { ступінь, РМА }\end{array}$ & $\begin{array}{c}\text { тяжкий } \\
\text { ступінь, РМА }\end{array}$ \\
\hline $18-26$ & $24,12 \pm 2,15^{\circ}$ & $39,27 \pm 2,45^{\circ}$ & $63,14 \pm 2,85$ & $15,26 \pm 2,03$ & $28,20 \pm 2,18$ & - \\
\hline $27-35$ & - & $47,29 \pm 2,30^{\circ \circ}$ & $70,21 \pm 2,32^{\circ \circ}$ & $21,10 \pm 2,12$ & $37,86 \pm 2,22$ & $63,14 \pm 2,09$ \\
\hline $\begin{array}{c}\text { Середнє } \\
\text { значення }\end{array}$ & $24,12 \pm 2,15$ & $43,28 \pm 2,38^{\circ}$ & $66,68 \pm 2,59$ & $18,18 \pm 2,08$ & $33,03 \pm 2,20$ & $63,14 \pm 2,09$ \\
\hline
\end{tabular}

Примітка. ${ }^{\circ}-\mathrm{p}<0,01 ;^{\circ}-\mathrm{p}<0,05$ - достовірна різниця значень стосовно даних порівняльної групи. 
му ступені ХКГ значення індексу РМА перевищували аналогічні дані в їх однолітків у групі порівняння в 1,6 раза $(24,12 \pm 2,15) \%$ проти $(15,26 \pm 2,03) \%, p<0,01$. У цій же віковій групі при середньому ступені ХКГ у пацієнтів зі скупченням зубів значення індексу РМА дорівнювало $(39,27 \pm 2,45) \%$, що було у 1,4 раза вище стосовно даних в осіб без ортодонтичної патології цієї ж вікової категорії, $\mathrm{p}<0,01$.

При тяжкому ступені ХКГ у пацієнтів основної групи віком 18-26 років значення РМА було максимальним та складало $(63,14 \pm 2,85) \%$.

В осіб з ортодонтичною патологією віком 27-35 років при середньому ступені ХКГ зна- чення індексу PMA перевищувало аналогічні дані у пацієнтів порівняльної групи тієї ж вікової категорії у 1,2 раза $(47,29 \pm 2,30) \%$ проти $(37,86 \pm 2,22) \%, p<0,05$. При тяжкому ступені ХКГ у досліджуваних основної групи віком 27-35 років значення індексу РМА складало $(70,21 \pm 2,32)$ $\%$ та було вище стосовно даних в їх однолітків у групі порівняння - $(63,14 \pm 2,09) \%, \mathrm{p}<0,05$.

У результаті проведених досліджень ми встановили (рис. 2), що у 18-26-річних пацієнтів основної групи середнє значення індексу кровоточивості становило $(1,93 \pm 0,04)$ бала проти $(1,10 \pm 0,02)$ бала у досліджуваних цієї ж вікової категорії порівняльної групи, $\mathrm{p}<0,01$.

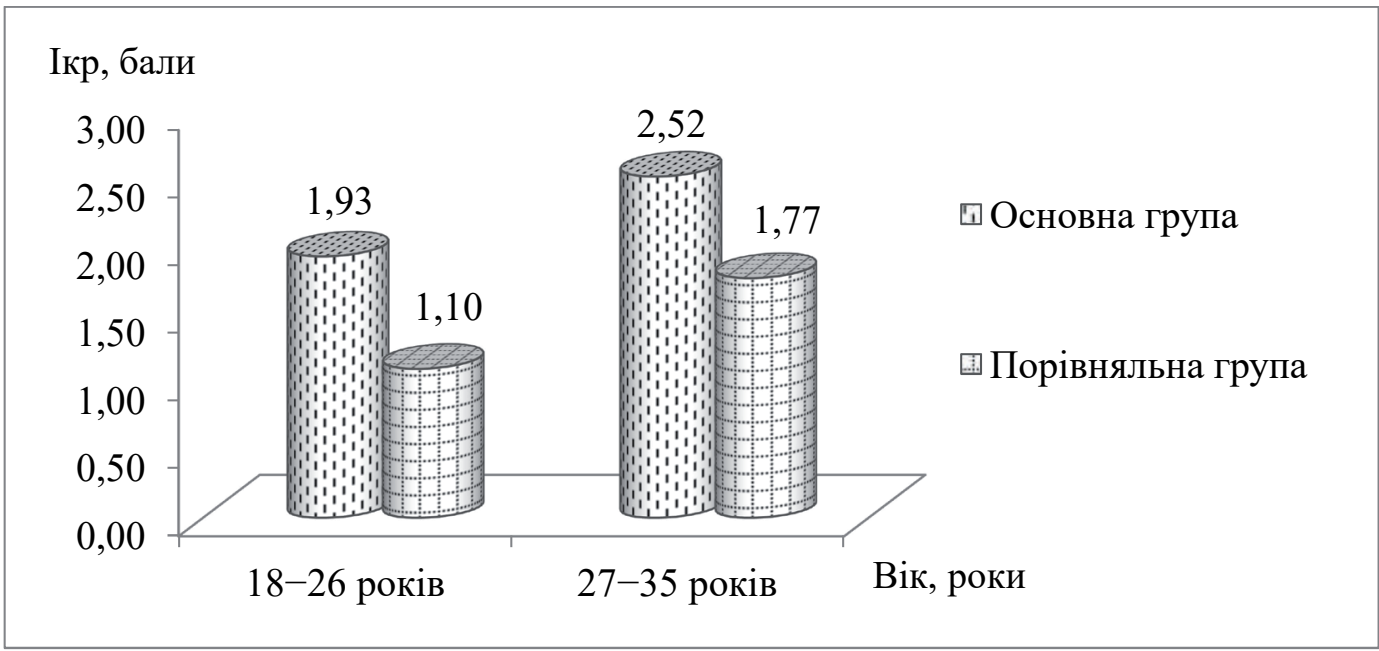

Puc. 2. Середні значення індексу кровоточивості ясен у пацієнтів груп дослідження залежно від віку.

Зі збільшенням віку обстежених обох груп дослідження, визначали зростання даних індексу кровоточивості: до $(2,52 \pm 0,04)$ бала в основній та до $(1,77 \pm 0,04)$ бала у порівняльній групах, $\mathrm{p}<0,01$. Варто зауважити, що у пацієнтів основної групи значення індексу кровоточивості ясен у середньому було в 1,2 раза більше стосовно даних у порівнянні $(2,01 \pm 0,04)$ бала проти $(1,66 \pm 0,03)$ бала, $\mathrm{p}<0,01$.

Звертало увагу, що зі збільшенням ступеня тяжкості ХКГ індексні значення кровоточивості ясен зростали в обох групах до- слідження. Однак у 18-26-річних пацієнтів індекс кровоточивості ясен при легкому та середньому ступенях ХКГ був у 1,5 раза вище стосовно даних в їх однолітків у групі порівняння, $\mathrm{p}<0,01$. При тяжкому ступені ХКГ у пацієнтів віком 18-26 років значення індексу кровоточивості ясен було найвищим та становило $(2,54 \pm 0,04)$ бала. В осіб у віці 27-35 років при середньому та тяжкому ступенях ХКГ індекси кровоточивості порівняно перевищували значення у 1,2 раза, $\mathrm{p}<0,01$ (табл. 2).

Таблищя 2. Значення індексу кровоточивості ясен при різних ступенях хронічного катарального гінгівіту в пацієнтів груп дослідження залежно від віку

\begin{tabular}{|c|c|c|c|c|c|c|}
\hline \multirow{2}{*}{$\begin{array}{c}\text { Вікова } \\
\text { група, роки }\end{array}$} & \multicolumn{3}{|c|}{ Основна група } & \multicolumn{3}{c|}{ Порівняльна група } \\
\cline { 2 - 6 } & $\begin{array}{c}\text { легкий } \\
\text { стуінь, Ікр }\end{array}$ & $\begin{array}{c}\text { середній } \\
\text { тупінь, Ікр }\end{array}$ & $\begin{array}{c}\text { тяжкий } \\
\text { ступінь, Ікр }\end{array}$ & $\begin{array}{c}\text { легкий } \\
\text { ступінь, Ікр }\end{array}$ & $\begin{array}{c}\text { середній } \\
\text { ступінь, Ікр }\end{array}$ & $\begin{array}{c}\text { тяжкий } \\
\text { ступінь, Ікр }\end{array}$ \\
\hline $18-26$ & $1,26 \pm 0,06^{\circ}$ & $1,98 \pm 0,03^{\circ}$ & $2,54 \pm 0,04$ & $0,86 \pm 0,03$ & $1,34 \pm 0,02$ & - \\
\hline $27-35$ & - & $2,06 \pm 0,04^{\circ}$ & $2,98 \pm 0,05^{\circ}$ & $1,10 \pm 0,04$ & $1,76 \pm 0,03$ & $2,45 \pm 0,04$ \\
\hline $\begin{array}{c}\text { Середнє } \\
\text { значення }\end{array}$ & $1,26 \pm 0,06^{\circ}$ & $2,02 \pm 0,03^{\circ}$ & $2,76 \pm 0,04^{\circ}$ & $0,98 \pm 0,03$ & $1,55 \pm 0,02$ & $2,45 \pm 0,04$ \\
\hline
\end{tabular}

Примітка. ${ }^{\circ}-$ p $<0,01$ - достовірна різниця значень стосовно даних порівняльної групи. 
За індексом CPI, у пацієнтів зі скупченням зубів у середньому на одного обстеженого припадало $(4,25 \pm 0,14)$ ураженого секстанта проти $(1,78 \pm 0,12)$ ураженого секстанта в осіб без ортодонтичної патології, $\mathrm{p}<0,01$.

Значення індексу СРI у пацієнтів груп дослідження, залежно від віку, представлено на рисунку 3. У результаті проведених досліджень визначено, що в пацієнтів основної групи віком 18-26 років зі скупченням зубів у серед- ньому припадало $(4,07 \pm 0,13)$ ураженого секстанта на одного обстеженого проти $(3,15 \pm 0,12)$ ураженого секстанта в осіб порівняльної групи такого ж віку, p<0,01. Разом з тим, у пацієнтів зі скупченням зубів цієї вікової групи визначали у 1,5 раза менше здорових секстантів $(1,93 \pm 0,11$ проти $2,85 \pm 0,12, \mathrm{p}<0,01)$.

У пацієнтів зі скупченням зубів віком 27-35 років досліджували $(4,42 \pm 0,12)$ ураженого секстанта, що було достовірно більше, ніж у

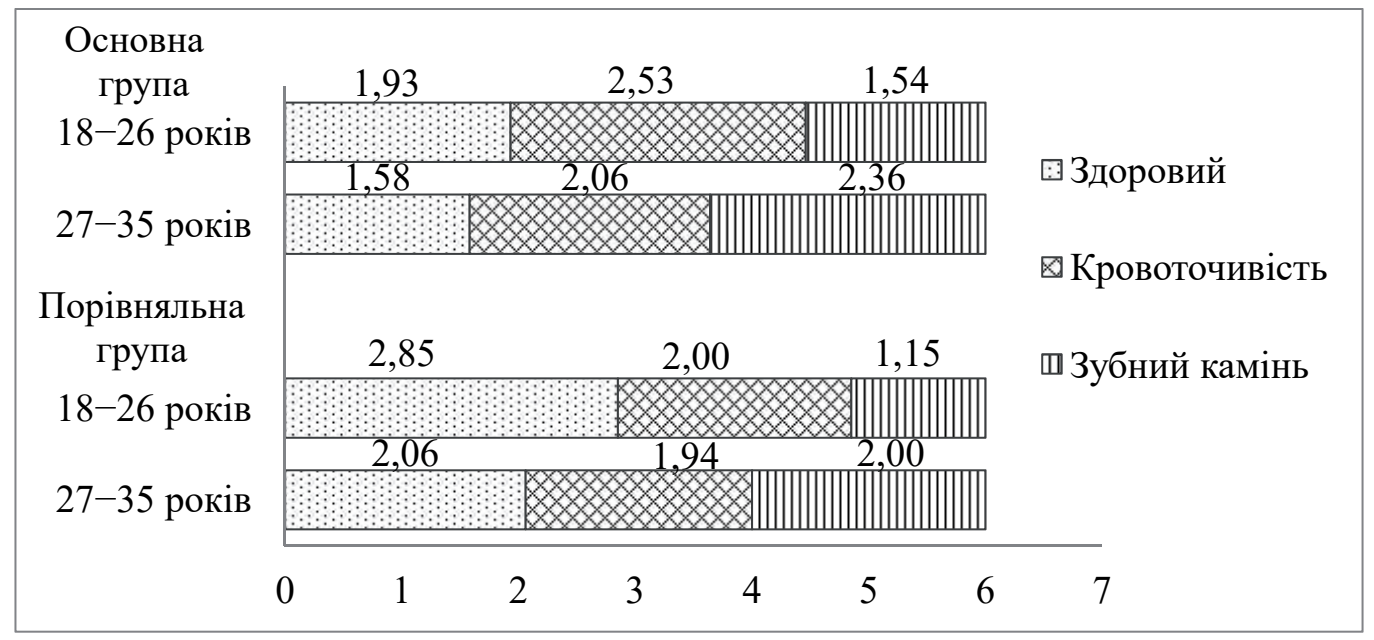

Puc. 3. Показники індексу CPI у пацієнтів груп дослідження залежно від віку.

осіб без ортодонтичної патології - $(3,94 \pm 0,13)$ $\mathrm{p}<0,05$. Звертало увагу, що в досліджуваних основної групи у віці 27-35 років кількість здорових секстантів була у 1,3 раза менше, ніж у людей групи порівняння цієї ж вікової групи.

\section{Список літератури}

1. Аболмасов Н. Г. Ортодонтия : учеб. пособ. / Н. Г. Аболмасов, Н. Н. Аболмасов. - М. : Медпресс-информ, 2008. - 424 с.

2. Бандрівський Ю. Л. Мікрогемодинаміка пародонта при гінгівіті / Ю. Л. Бандрівський, Н. Н. Бандрівська, О. В. Авдєєв // Матеріали III (X) з'їзду Асоціації стоматологів України. - Полтава, 2008. - С. 122-123. 3. Запальні захворювання пародонта / Т. Д. Заболотний, А. В. Борисенко, Т. І. Пупін. - Львів : ГалДент, 2013. - 205 c.

4. Леонтьев В. К. Концепция патогенеза пародонтита при изменении локальной функциональной перегрузки / В. К. Леонтьев, Ю. А. Петрович // Сборн. науч. тр. «Актуальные вопросы стоматологии». - М., 2004. - C. $18-24$.

5. Нетцель Ф. Практическое руководство по ортодонтии / Ф. Нетцель, К. Шультц. - Львов : ГалДент, 2006. - 176 c.

6. Олейник Е. А. Основные стоматологические забо-
Висновки. В осіб зі скупченням зубів на тлі хронічного катарального гінгівіту інтенсифікація запальних процесів у тканинах пародонта збільшувалась 3 віком, залежала від ступеня тяжкості ХКГ та була вищою, ніж у обстежених без ортодонтичної патології.

левания и зубочелюстные аномалии (особенности патогенеза, диагностики, клиники и профилактики) : автореф. дисс. на соискание уч. степени канд. мед. наук : спец. 14.00.21 «Стоматология» / Е. А. Олейник. - Воронеж, 2008. - 22 с.

7. Хорошилкина Ф. Я. Ортодонтия. Дефекты зубов, зубных рядов, аномалии прикуса, морфофункциональные нарушения в челюстно-лицевой области и их комплексное лечение / Ф. Я. Хорошилкина. - М. : Мед. информ. агентство, 2006. - 544 c.

8. Mandall N. A. Prediction of compliance and completion of orthodontic treatment: are quality of life measures important ? / N. A. Mandall // Eur. J. Orthod. 2012. - Vol. 30, No. 1. - P. 40-45.

9. Petersen P. E. The global burden of oral diseases and risk to oral health / P. E. Petersen // Bull. World Health Organ. - Vol. 83, No. 9. - 2015. - P. 661-669. 


\section{References}

1. Abolmasov, N.H., \& Abilmasov, N.N. (2008). Ortodontiya [Orthodontics]. Moscow: Medpress-inform [in Russian].

2. Bandrivskyi, Yu.L., Bandrivska, N.N., \& Avdieiev, O.V. (2008). Mikrohemodynamika parodonta pry hinhiviti [Microhemodynamics of the parodontium at gingivitis]. Proceedings of III $(X)$ Congress of the Association of Ukrainian dentists. (pp. 122-123). Poltava [in Ukrainian]. 3. Zabolotnyi, T.D., Borysenko, A.V., \& Pupin, T.I. (2013). Zapalni zakhvoriuvannia parodonta [Inflammatory periodontal diseases]. Lviv: HalDent [in Ukrainian].

4. Leontyev, V.K., \& Petrovich, Yu. A. (2004). Kontseptsiya patogeneza parodontita pri izmeneniyi lokalnoy funktsionalnoy peregruzki [The conception of the pathogenesis of periodontitis at the change of local function overloading]. Aktualnye voprosy stomatologii - Actual Questions of Dentistry. Proceedings of the Scientific Papers. (pp. 18-24). Moscow [in Russian].

5. Nettsel, F., \& Shults, K. (2006). Prakticheskoye rukovodstvo po ortodontii [A practical guide to orthodontics]. Lviv: HalDent [in Russian].

6. Oleynik, E.A. (2008). Osnovnye stomatologicheskiye zabolevaniya i zubochelustnyye anomalii (osobennosti patogeneza, diagnostiki, kliniki i profilaktiki) [The main dental diseases and dental abnormalities (features of pathogenesis, diagnostics, clinic and prevention)]. Extended abstract of Candidate's thesis. Voronezh [in Russian].

7. Khoroshylkina, F.Ya. (2006). Ortodontiya. Defekty zubov, zubnykh ryadov, anomalii prikusa, morfofunktsionalnye narusheniya $v$ chelustno-litsevoy oblasti $i$ ikh kompleksnoye lecheniye [Orthodontics. Defects of the teeth, dentition, malocclusion, morphological and functional disorders in the maxillofacial area and their complex treatment]. Moscow: Med. inform. agenstvo [in Russian].

8. Mandall, N. A. (2012). [Prediction of compliance and completion of orthodontic treatment: are quality of life measures important?]. European Journal of Orthodontics, 1, 40-45.

9. Petersen, P. E. (2015). [The global burden of oral diseases and risk to oral health] Bulletin of World Health Organization, 9, 661-669.

Отримано 26.09.17 